\title{
Survival and Growth Characteristics of Escherichia coli O157:H7 in Pomegranate-Carrot and Pomegranate-Apple Blend Juices
}

\author{
Salam A. Ibrahim, Tarik Bor, Danfeng Song, Mehrdad Tajkarimi \\ Food and Nutritional Sciences, North Carolina Agricultural and Technical State University, Greensboro, USA. \\ Email: Tajkarimi@gmail.com
}

Received June $10^{\text {th }}, 2011$; revised July $21^{\text {st }}, 2011$; accepted July $28^{\text {th }}, 2011$.

\begin{abstract}
Unpasteurized fruit juice has been implicated in outbreaks of Escherichia coli O157:H7 (E. coli O157:H7). Meanwhile, certain fruit, such as pomegranate, contains antimicrobial components. The objective of this study was to investigate the survival and growth characteristics of E. coli O157:H7 on pomegranate juice in laboratory medium and in pomegranate-carrot and pomegranate-apple blend juices at different concentrations. Single strain of E. coli O157:H7 (E0019, H1730, and Cider) was inoculated into brain heart infusion (BHI) broth or a mixture of three strains was inoculated into the blended juices containing pomegranate juice. Our results showed that the addition of pomegranate juice inhibited the growth of tested E. coli O157:H7 in both laboratory medium and blended juices. The antimicrobial activity increased with increased concentrations of pomegranate juice $(P<0.001)$ and incubation times. The bacterial population was reduced by at least 2 log CFU/ml in BHI broth and juice blend samples in the presence of 20\% and 40\% Pome- granate juice respectively. Sensory evaluations performed using a 9 point hedonic scale showed significant satisfac- tion on using $40 \%$ pomegranate juice blend with carrot and apple juices. Our study suggests that pomegranate juice could be used as a natural antimicrobial in different food systems including juices to inhibit the growth of E. coli O157:H7.
\end{abstract}

Keywords: Escherichia coli O157:H7, Pomegranate Juice, Antimicrobial Activity

\section{Introduction}

Foodborne pathogen contamination is a major concern for the food processing industry, food producers, regulatory agencies, and consumers. Escherichia coli O157:H7 is a major virulent foodborne pathogen that was identified in the early 1980s [1]. Enterohaemorrhagic Escherichia coli (EHEC) which includes the well-known pathogenic strain O157:H7 has emerged as a major source of foodborne outbreaks, has and has been estimated to be the cause of approximately 9000 human illnesses and 70 deaths per year in the United States, incurring a cost of more than $\$ 1$ billion USD [2]. Some of the more symptomatic effects of EHEC include bloody diarrhea, hemolytic uremic syndrome (HUS), and thrombotopenic purpura (TTP). A number of food products have been associated with this pathogen including milk, ground beef, lettuce, melon, green onions, spinach, tomatoes, carrot juice and apple cider $[3,4]$.

With greater availability of information about the health impacts, consumers are now not only paying closer attention to the risk of foodborne pathogens but also the presence of synthetic preservatives. As a result, the food industry is looking to use more natural food preservatives that have strong antimicrobial activity to ensure safe wholesome food products. Natural components, especially those from plants, can be used for food preservation and offer potential health benefits. For example, essential oils from plants such as basil, cumin, and oregano have been shown to inhibit different foodborne pathogens [5-7]. Antimicrobial compounds present in different fruit or vegetable extracts inhibit the growth of E. coli $\mathrm{O} 157: \mathrm{H} 7$ and other pathogenic and spoilage microorganisms [8-12]. Cornus fruit extract significantly inhibited the growth of E. coli $\mathrm{O} 157: \mathrm{H} 7$ in apple juice and therefore Cornus fruit could be used to improve quality of apple juice [13]. Pomegranate (Punica granatum, Punicaceae), is an edible fruit cultivated in Mediterranean countries, Afghanistan, India, China, Japan, Russia, and some parts of the United States. Pomegranate fruit is widely used in the food industry due to its excellent nutritional and health value [14]. Pomegranate benefits the cardiovascular 
system [15] and pomegranate juice can be used as a cancer chemopreventive agent [16]. The extracts from various parts of the pomegranate plant also possess antibacterial, antifungal, antiviral, antidiarrheal activities. Pomegranate juice contains active phytochemicals, tannins and alkaloids, that have antimicrobial activity against several spoilage microorganisms [14,17-24]. A growing number of publications reveal direct antimicrobial effect of pomegranate against both gram-positive, gram-negative bacteria and their enterotoxins in food and laboratory medium $[20,23,25,26]$.

Negi et al., 2003 found that pomegranate peel extract inhibited the growth of Escherichia coli by $60 \%$ at 150 ppm concentration and completely inactivated the growth of $E$. coli at $300 \mathrm{ppm}$ concentration. Fractions of ellagic acid, gallagic acid, punicallins, and punicalagins extracted from pomegranate showed antimicrobial activity against Escherichia coli, Pseudomonas aeruginosa, methicillin-resistant Staphylococcus aureus, and other harmful bacteria [23]. Our preliminary laboratory results showed antimicrobial activity of pomegranate juice and $E$. coli did not survive in pomegranate juice alone with counts below detectable level $<2.00$ in all samples. The objective of this study was to determine pomegranate juice antimicrobial activity against E. coli $\mathrm{O} 157: \mathrm{H} 7$ in apple/carrot juice blend with pomegra- nate juice.

\section{Materials and Methods}

\subsection{Bacterial Strains}

Three strains of E.coli O157:H7 were supplied by Dr. S.S. Sumner, Department of Food Science and Technology, Virginia Tech. These strains were E0019 (beef isolate), H1730 (human isolate from an outbreak associated with lettuce) and Cider (cider isolate). These strains were maintained on brain heart infusion (BHI) (Difco, Becton Dickinson, Cockeysville, MD, USA) agar slants at $4^{\circ} \mathrm{C}$ and transferred to fresh BHI broth before use. Cultures of each strain were grown separately in $\mathrm{BHI}$ broth at $37^{\circ} \mathrm{C}$ and transferred at $24 \mathrm{~h}$ intervals.

\subsection{Preparation of Mixture Strains}

Overnight cultures of each strain were serially diluted in sterilized $0.1 \%$ peptone water to achieve a final inoculum level of approximately $3.0 \log \mathrm{CFU} / \mathrm{ml}$ and $1 \mathrm{ml}$ of each diluted strain was combined into a sterilized empty tube to produce a mixture of three strains. The initial population count was confirmed by spread plating dilutions onto duplicate BHI agar. Colonies were counted after plates were incubated at $37^{\circ} \mathrm{C}$ for $24 \mathrm{~h}$.

\subsection{Preparation of Juice Samples}

Fresh organic pomegranate, carrot and apple juices were purchased from a local store (Greensboro, NC, USA) the day before each use and stored at $4^{\circ} \mathrm{C}$. These products were freshly prepared and did not contain any food preservatives and not made from concentrate. In preparation for use as a growth medium, juice was steam-sterilized at $115^{\circ} \mathrm{C}$ for 13 min to inactivate natural flora and then cooled to $37^{\circ} \mathrm{C}$.

\subsection{Antimicrobial Activity of Pomegranate Juice in BHI}

One hundred $\mathrm{mL}$ batches of BHI broth were prepared and autoclaved at $121^{\circ} \mathrm{C}$ for $15 \mathrm{~min}$. Pomegranate juice was then added to make final concentrations of $0 \%, 5 \%, 10 \%, 20 \%$, $40 \%$ and $60 \%$ and mixed well. Single strains of E. coli O157:H7 were inoculated individually into BHI broth and pomegranate juice mixtures to achieve initial inoculum level of approximately $3.0 \log \mathrm{CFU} / \mathrm{ml}$ and incubated at $37^{\circ} \mathrm{C}$ for 24 h. During the incubation period, $1 \mathrm{~mL}$ from each sample was individually withdrawn at $0,2,4,6,8$, and $24 \mathrm{~h}$ time intervals to determine the population of E. coli O157:H7.

\subsection{Antimicrobial Activity of Pomegranate Juice in Carrot or Apple Juice Blend}

To assess E. coli $\mathrm{O} 157: \mathrm{H} 7$ growth in juices, $100 \mathrm{~mL}$ batches of sterilized carrot (pH 5.8) and apple juices (pH 4.5) were prepared. Pomegranate juice was then added at concentrations of $0 \%, 5 \%, 10 \%, 20 \%, 40 \%, 60 \%$ and $\% 100$ and mixed well. The final $\mathrm{pH}$ value of each treatment was recorded using a $\mathrm{pH}$ meter ( $\mathrm{pH}$ meter Fisher Model XL 60F, Pittsburgh, PA). Blended juice samples were then inoculated with a mixture of $E$. coli strains to achieve final inoculum level of $7.0 \mathrm{log}$ $\mathrm{CFU} / \mathrm{ml}$. Samples were then incubated at $37^{\circ} \mathrm{C}$ for $24 \mathrm{~h}$ to determine the survival and growth of E. coli $\mathrm{O} 157: \mathrm{H} 7$ mixture strains in both pomegranate-carrot and pomegranateapple blend juices.

\subsection{Bacterial Enumerations}

Bacterial populations were determined by plating onto BHI agar. In this procedure, samples $(1 \mathrm{~mL})$ were withdrawn from inoculated samples at intervals of $0,2,4,6,8$ and $24 \mathrm{~h}$, serially diluted in $0.1 \%$ peptone water and then appropriate dilutions were surface plated $(100 \mu \mathrm{L})$ onto duplicate BHI agar. Colonies were counted after plating $24 \mathrm{~h}$ at $37^{\circ} \mathrm{C}$ to determine E. coli population.

\subsection{Experimental Design}

The design for the BHI broth experiment was a complete $3 \times 6 \times 6$ factorial design of $E$. coli O157:H7 strains (E0019, H1730 and Cider), pomegranate juice concentrations ( $0 \%$, $5 \%, 10 \%, 20 \%, 40 \%$ and $60 \%)$ and incubation times $(0,2,4$, 6,8 , and $24 \mathrm{~h}$ ). In the case of blended juice samples, the experimental design was a $6 \times 6$ factorial design with only mixture strains of $E$. coli $\mathrm{O} 157: \mathrm{H} 7$, pomegranate juice concentrations $(0 \%, 5 \%, 10 \%, 20 \%, 40 \%, 60 \%$ and $100 \%)$ and 
incubation times $(0,2,4,6,8$, and $24 \mathrm{~h})$. The bacterial population in each sample was monitored by plating onto BHI agar at different time intervals during the incubation period.

\subsection{Sensory Evaluation}

The sensory evaluation was conducted using a nine unit hedonic scale by thirty five semi trained panels. The hedonic scale of appearance, color, texture, taste, smell and overall acceptance is conducted.

\subsection{Statistical Analysis}

The experiments were conducted three times, independently, to determine whether the addition of pomegranate juice would influence the growth of E. coli O157:H7. The microbiological data were analyzed by the general linear model (GLM) procedure of SAS/STAT software (SAS Institute Inc., Cary, NC). T-test was applied and $\alpha=0.05$ was selected for determination of statistical significance.

\section{Results and Discussion}

Figures 1-3 illustrate the effect of pomegranate juice on the growth inhibition of $E$. coli O157: H7. The average initial population of E. coli $\mathrm{O} 157: \mathrm{H} 7$ was about $3.6 \log \mathrm{CFU} / \mathrm{ml}$. When E. coli O157:H7 (strain E0019) was grown in BHI without pomegranate juice, the bacterial population reached $8.0 \log \mathrm{CFU} / \mathrm{ml}$ within $24 \mathrm{~h}$. The addition of 5\% pomegranate juice caused a slight reduction $(7.2 \log \mathrm{CFU} / \mathrm{ml})$ in the bacterial population within $8 \mathrm{~h}$ and $7.9 \log \mathrm{CFU} / \mathrm{ml}$ after
$24 \mathrm{~h}$. The addition of $10 \%$ pomegranate juice to BHI produced a further but non-significant (compared to control) reduction. At concentrations of $20 \%$ and $40 \%$ of pomegranate juice, there was significant reduction compared to the control, with counts of 6.14 and $5.17 \log \mathrm{CFU} / \mathrm{ml}$ respectively $(\mathrm{P}<0.05)$ after 24 hours incubation. The addition of $60 \%$ pomegranate juice to BHI broth caused significant growth inhibition of $E$. coli $\mathrm{O} 157: \mathrm{H} 7$ (3.6 log CFU reduction) when compared to all the other treated and control samples (Figure 1).

Figure 2 shows the growth of E. coli $\mathrm{O} 157: \mathrm{H} 7$ (strain $\mathrm{H}$ 1730) in BHI with the presence of pomegranate juice at different concentrations. The bacterial populations reached $9.1 \log \mathrm{CFU} / \mathrm{ml}$ within $24 \mathrm{~h}$ in the control sample. The addition of pomegranate juice $(5 \%)$ achieved a significant reduction (7.0 log CFU/ml) compared to the control, within $24 \mathrm{~h}(\mathrm{P}<0.05)$. These results were also aligned with the study done on the antimicrobial activity of pomegranate's bark and rind against $E$. coli [25]. These results confirm that the $\mathrm{H} 1730$ strain is more sensitive to pomegranate juice than both E0019 and Cider strains. With 10\% and 20\% of pomegranate juice concentration, bacterial population reduced to 6.5 and $6.2 \log \mathrm{CFU} / \mathrm{ml}$, respectively within $24 \mathrm{~h}$. Substantially, greater reductions were achieved with $40 \%$ pomegranate juice $(4.9 \log \mathrm{CFU} / \mathrm{ml})$. Finally, with the addition of $60 \%$ pomegranate juice, the bacterial population reached $3.9 \log$ CFU/ml which was significantly different when compared with the other concentrations (differrences

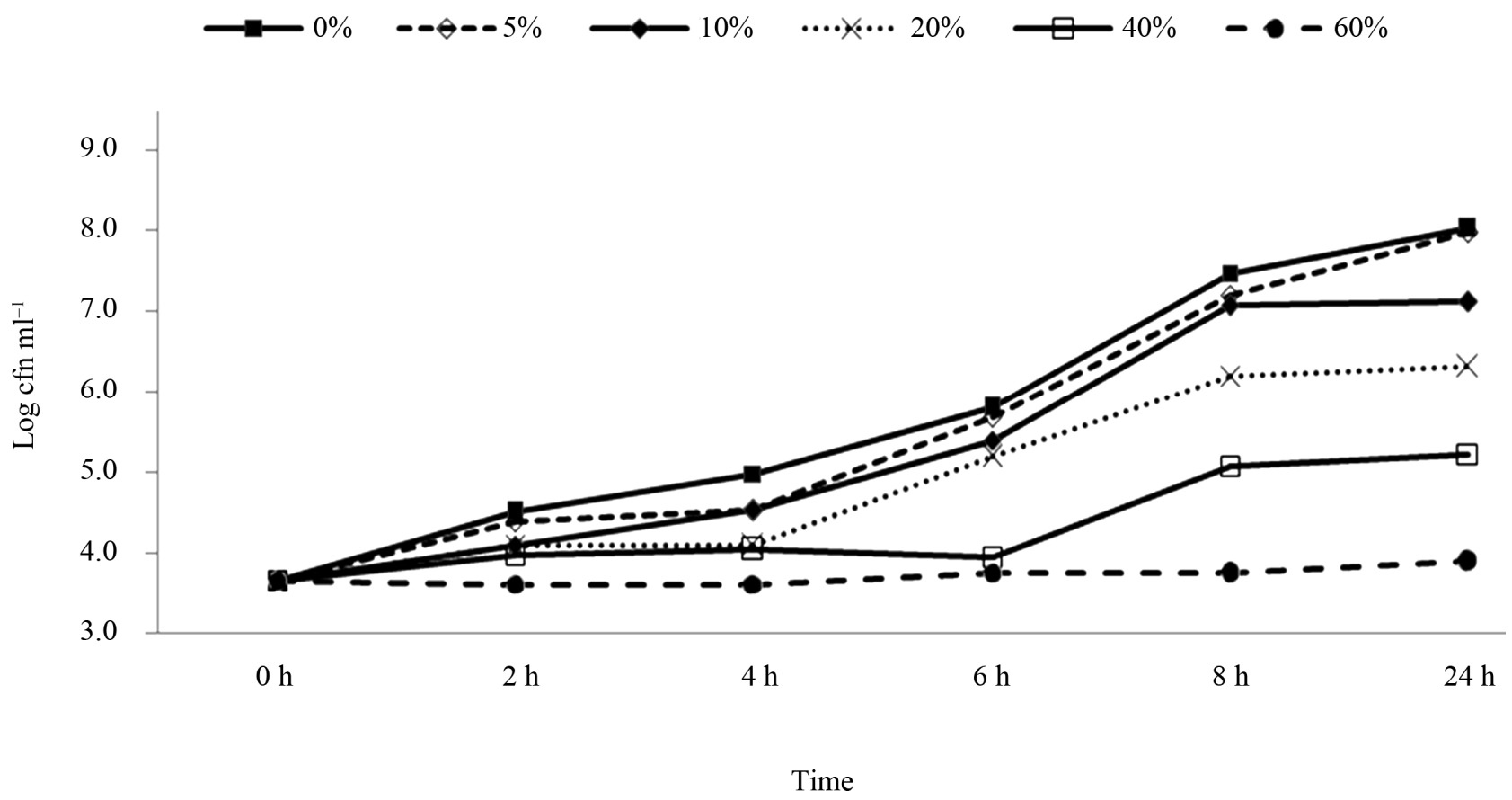

Figure 1. Survival and growth of E.coli O157: H7 (strain E0019) in BHI broth with presence of pomegranate juice at different concentrations. 


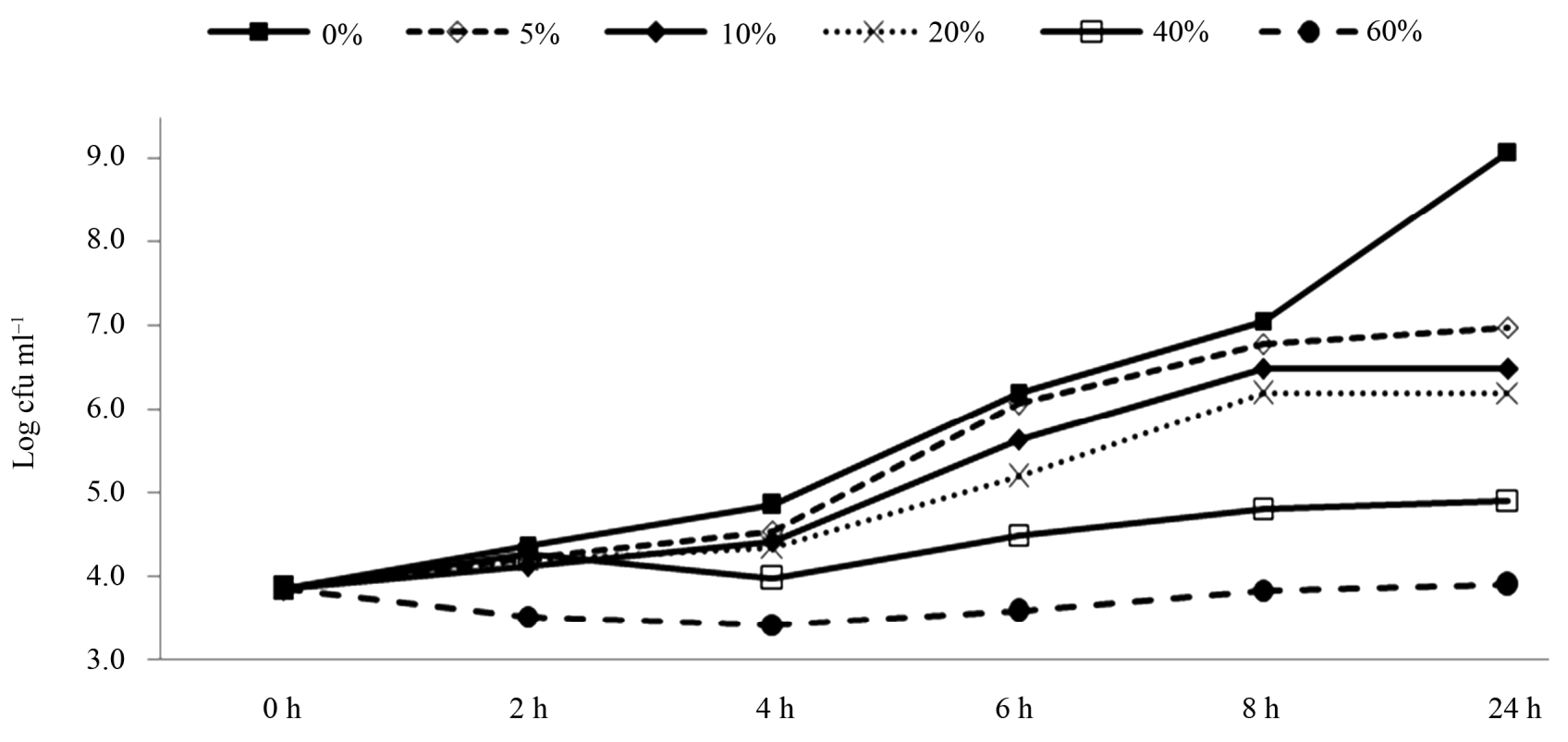

Time

Figure 2. Survival and growth of E.coli O157: H7 (strain H1730) in BHI broth with presence of pomegranate juice at different concentrations.

were 5.2, 3.1, 2.6, 2.1 and $1.0 \log \mathrm{CFU} / \mathrm{ml}$ with $0 \%, 5 \%$, $10 \%, 20 \%$, and $40 \%$, respectively).

The results of $E$. coli $\mathrm{O} 157: \mathrm{H} 7$ (Cider strain) in the presence of pomegranate juice are presented in Figure 3. The bacterial populations reached $9.0 \log \mathrm{CFU} / \mathrm{ml}$ within $24 \mathrm{~h}$ in the control samples. The significant inhibition in bacterial growth was observed with all concentrations of pomegranate juice $(\mathrm{P}<0.05)$. The results showed that the reduction levels of the Cider strain $E$. coli $\mathrm{O} 157: \mathrm{H} 7$ was less in comparison to H1730 and E0019 strains. The comparison between strains was conducted by calculating the mean $\log$ CFU reduction in each strain treatment. For example, according to Figures 1-3, adding 5\% pomegranate juice to strain $\mathrm{H} 1730$ in BHI broth reduced $2.2 \mathrm{log}$ $\mathrm{CFU} / \mathrm{ml}, 0.8 \log \mathrm{CFU} / \mathrm{ml}$ in strain cider and $0.1 \log \mathrm{CFU} / \mathrm{ml}$ in strain E0019. So the treatment effect was calculated to be $1.03 \pm 1.06$.

Table 1 shows the survival and growth of the mixture strains of $E$. coli $\mathrm{O} 157: \mathrm{H} 7$ grown in pomegranate-carrot blend juice. The initial bacterial populations in all samples were $\sim 7.45 \log \mathrm{CFU} / \mathrm{ml}$. E. coli growth in carrot juice without pomegranate juice, reached an average of $8.97 \log \mathrm{CFU} / \mathrm{ml}$ after $24 \mathrm{~h}$ incubation. The growth of $E$. coli reduced significantly $(\mathrm{P}<0.05)$ in the pomegranate-carrot blend juice at all concentrations, compared to their control condition. Bacterial population decreased with increased concentration of pomegranate juice.

Table 2 shows the growth and survival of the mixture strains of $E$. coli $\mathrm{O} 157: \mathrm{H} 7$ in pomegranate-apple juice blend. $E$. coli growth in apple juice without pomegranate juice slightly decreased within $8-10 \mathrm{~h}$ and remained the same after $24 \mathrm{~h}$. The slight growth inhibition was probably due to the acidic environment of apple juice. In pomegranate-apple juice blend, bacterial population was significantly $(\mathrm{P}<0.05)$ lower than the control. However, there was no significant reduction difference between $60 \%$ and $40 \%$ concentration levels. Addition of non-blended pomegranate juice caused a significant bacterial inhibition and reached below detection level $(10 \leq \mathrm{CFU} / \mathrm{ml})$ for $E$. coli $\mathrm{O} 157: \mathrm{H} 7$ (Tables 1 and 2). According to Tables 3 and 4, the sensory evaluation showed that the blends of $40 \%$ pomegranate with carrot juice were widely and significantly $(\mathrm{P}<0.05)$ accepted in all categories compared to the regular carrot juice. The acceptance level for the blend of apple and pomegranate juice was also higher than apple juice. Despite some reports about the lethal effect of low $\mathrm{pH}$, several outbreaks have been reported even in acidified food. It has been reported that E. coli O157:H7 survived well at $\mathrm{pH}$ values of below 3.4 in acidic fruits and juices. Results of the current study indicate that the $\mathrm{pH}$ (acidic property) would not be a key factor for influencing the survival of $E$. coli $\mathrm{O} 157: \mathrm{H} 7$ [27]. Pomegranate juice is emerging as a new functional food due to its considerable anthocyanin content and ellagitannin punicalagins and pomegranate by-product $[28,29]$. Antimicrobial activity of pomegranate peel extract against pathogenic microorganisms such 

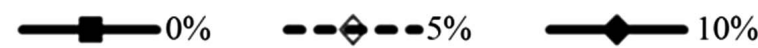

•...… 20\%

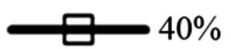

$-60 \%$

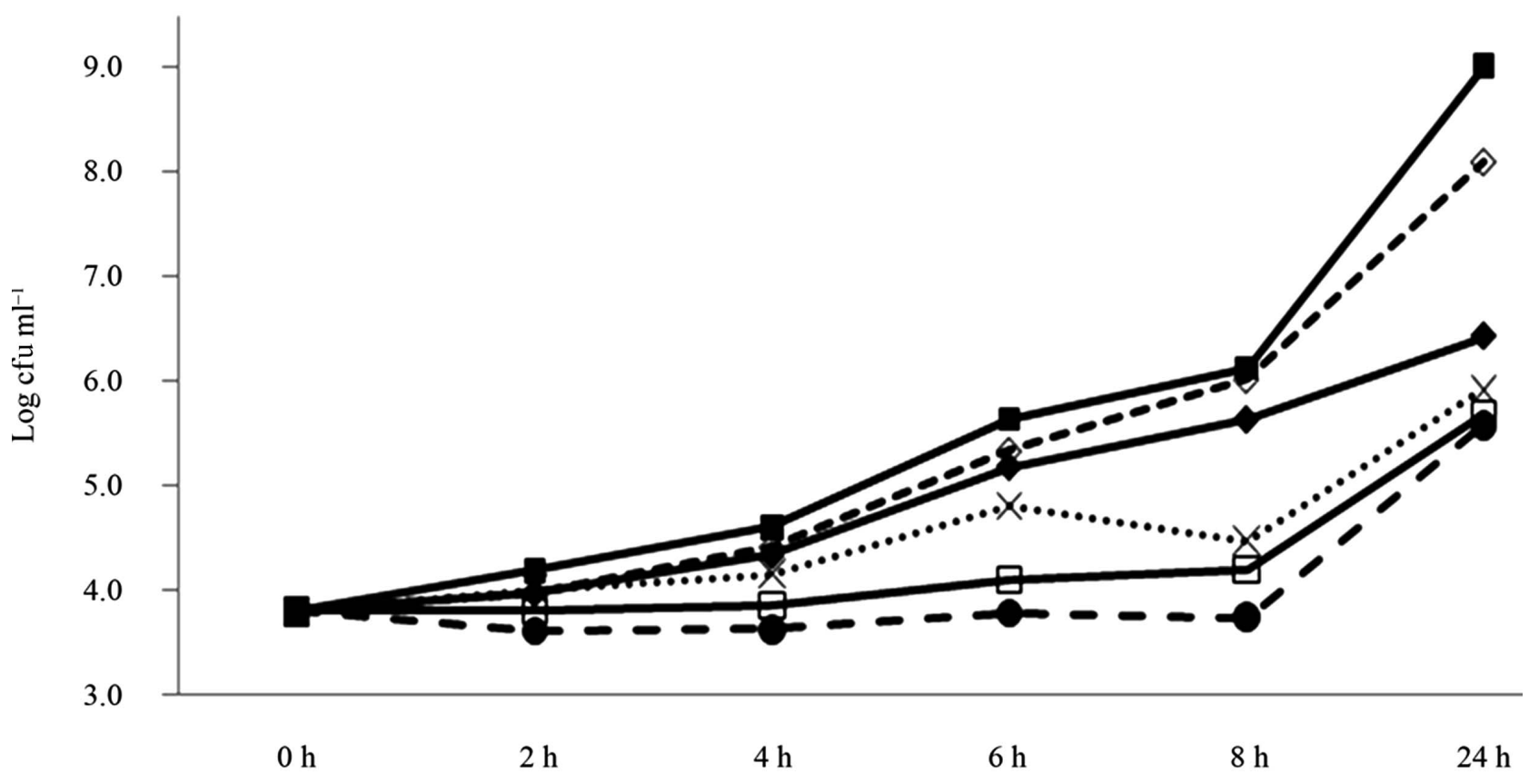

Time

Figure 3. Survival and growth of E.coli O157: H7 (strain Cider) in BHI broth with presence of pomegranate juice at different concentrations.

Table 1. Survival and growth of E. coli O157:H7 (log CFU/ml) in pomegranate-carrot blend juice samples.

\begin{tabular}{|c|c|c|c|c|c|c|}
\hline \multirow{2}{*}{ Concentration } & \multicolumn{6}{|c|}{ Time (hour) } \\
\hline & 0 & 2 & 4 & 6 & 8 & 24 \\
\hline $0 \%$ & $7.45 \mathrm{a}^{*}$ & $8.23 \mathrm{a}$ & $8.64 \mathrm{a}$ & $8.75 \mathrm{a}$ & $8.17 \mathrm{a}$ & $8.97 \mathrm{a}$ \\
\hline $5 \%$ & $7.45 \mathrm{a}$ & $8.17 \mathrm{a}$ & $8.54 \mathrm{a}$ & $8.62 \mathrm{a}$ & $7.79 a$ & $7.34 \mathrm{~b}$ \\
\hline $10 \%$ & $7.45 \mathrm{a}$ & $8.01 \mathrm{a}$ & $8.34 \mathrm{a}$ & $8.41 \mathrm{a}$ & $7.59 \mathrm{a}$ & $6.96 \mathrm{c}$ \\
\hline $20 \%$ & $7.45 \mathrm{a}$ & $7.82 \mathrm{a}$ & $7.95 b$ & $8.05 \mathrm{~b}, \mathrm{c}$ & $7.35 \mathrm{~b}$ & $6.68 \mathrm{~d}$ \\
\hline $40 \%$ & $7.45 \mathrm{a}$ & $7.76 \mathrm{a}$ & $7.70 \mathrm{~b}$ & $7.65 \mathrm{c}$ & $7.02 b$ & $6.26 \mathrm{e}$ \\
\hline $60 \%$ & $7.45 \mathrm{a}$ & $7.60 \mathrm{a}$ & $7.60 \mathrm{~b}$ & $7.52 \mathrm{c}$ & $5.99 \mathrm{c}$ & $5.82 \mathrm{f}$ \\
\hline $100 \%$ & $7.45 \mathrm{a}$ & $\mathrm{ND}^{1}$ & ND & ND & ND & ND \\
\hline
\end{tabular}

\footnotetext{
${ }^{*}$ Means followed by the same letter within the same column are not significantly different at $\alpha=0.05 ;{ }^{1} \mathrm{ND}$ means below detectable level $<10 \mathrm{CFU} / \mathrm{ml}$.
} 
Table 2. Survival and growth of mixture strains of $E$. coli O157: $\mathrm{H} 7(\log \mathrm{CFU} / \mathrm{ml})$ in pomegranate-apple blend juice samples.

\begin{tabular}{|c|c|c|c|c|c|c|}
\hline \multirow{2}{*}{ Concentration } & \multicolumn{6}{|c|}{ Time (hour) } \\
\hline & 0 & 2 & 4 & 6 & 8 & 24 \\
\hline $0 \%$ & $7.37 \mathrm{a}^{*}$ & $7.34 \mathrm{a}$ & $7.07 \mathrm{a}$ & $7.02 \mathrm{a}$ & $7.00 \mathrm{a}$ & $6.98 \mathrm{a}$ \\
\hline $5 \%$ & $7.37 \mathrm{a}$ & $7.12 \mathrm{a}$ & $6.79 \mathrm{a}$ & $7.35 \mathrm{a}$ & $7.21 \mathrm{a}$ & $5.42 \mathrm{~b}$ \\
\hline $10 \%$ & $7.37 \mathrm{a}$ & $7.09 \mathrm{a}$ & $6.76 \mathrm{a}$ & $6.41 \mathrm{~b}$ & $6.26 \mathrm{~b}$ & $5.23 \mathrm{~b}$ \\
\hline $20 \%$ & $7.37 \mathrm{a}$ & $7.04 \mathrm{a}$ & $6.60 \mathrm{a}$ & $6.35 \mathrm{c}$ & $6.17 \mathrm{~b}$ & $5.10 \mathrm{~b}$ \\
\hline $40 \%$ & $7.37 \mathrm{a}$ & $7.02 \mathrm{a}$ & $6.36 \mathrm{a}$ & $6.24 \mathrm{c}$ & $6.02 \mathrm{c}$ & $4.35 \mathrm{c}$ \\
\hline $60 \%$ & $7.37 \mathrm{a}$ & $7.02 \mathrm{a}$ & $6.02 \mathrm{a}$ & $6.02 \mathrm{c}$ & $5.99 \mathrm{c}$ & $4.27 \mathrm{c}$ \\
\hline $100 \%$ & $7.37 \mathrm{a}$ & $\mathrm{ND}^{1}$ & ND & ND & ND & ND \\
\hline
\end{tabular}

*Means followed by the same letter within the same column are not significantly different at $\alpha=0.05 ;{ }^{1} \mathrm{ND}$ means below detectable level $<10 \mathrm{CFU} / \mathrm{ml}$.

Table 3. Sensory evaluation of blend of pomegranate juice with carrot juice.

\begin{tabular}{|c|c|c|c|}
\hline \multirow[t]{2}{*}{$\mathrm{S} / \mathrm{N}$} & \multirow[t]{2}{*}{ Parameter } & Carrot juice & $40 \%$ pomegranate and carrot juice \\
\hline & & \multicolumn{2}{|c|}{ Score } \\
\hline 1 & Appearance & 5.2 & 7.2 \\
\hline 2 & Color & 6.7 & 8.1 \\
\hline 3 & Texture & 6.3 & 7.8 \\
\hline 4 & Taste & 5.7 & 8.4 \\
\hline 5 & Smell & 6.1 & 7.8 \\
\hline 6 & Overall & 6.1 & 7.6 \\
\hline
\end{tabular}

Table 4. Sensory evaluation of blend of pomegranate juice with apple juice.

\begin{tabular}{|c|c|c|c|}
\hline \multirow[t]{2}{*}{$\mathrm{S} / \mathrm{N}$} & \multirow[t]{2}{*}{ Parameter } & Apple juice & $40 \%$ pomegranate and apple juice \\
\hline & & \multicolumn{2}{|c|}{ Score } \\
\hline 1 & Appearance & 7.2 & 8.1 \\
\hline 2 & Color & 5.8 & 7.2 \\
\hline 3 & Texture & 6.6 & 7.6 \\
\hline 4 & Taste & 5.8 & 9.9 \\
\hline 5 & Smell & 6.8 & 7.8 \\
\hline 6 & Overall & 5.9 & 7.4 \\
\hline
\end{tabular}


as Listeria monocytogenes, Staphylococcus aureus, and Salmonella enterica in cheese at room temperature was also demonstrated $[18,30]$. The bacterial population of $E$. coli O157:H7 grown in acidified BHI or carrot juice samples using hydrochloric acid ( $\mathrm{pH}$ value 4.05), decreased by only one $\log \mathrm{CFU} / \mathrm{ml}$. These results indicated that there might be another mechanism involved in the inhibition of bacterial growth other than the acidic medium. Antimicrobial effect of pomegranate juice and extracts have been reported in several articles and the antimicrobial activity might be due to its phenolic components [14,25,31].

\section{Conclusions}

Our results showed that pomegranate juice inhibited the growth of all tested strains of E. coli $\mathrm{O} 157: \mathrm{H} 7$ in the laboratory media and also in the juice blend. The antimicrobial activity increased with increased concentrations of pomegranate juice $(\mathrm{P}<0.001)$ and incubation times. The addition of $20 \%$ of pomegranate juice showed at least $2 \log \mathrm{CFU} / \mathrm{ml}$ reduction in the population of $E$. coli $\mathrm{O} 157: \mathrm{H} 7$ in $\mathrm{BHI}$ broth and the addition of $40 \%$ was needed to achieve at least 2 $\log \mathrm{CFU} / \mathrm{ml}$ reduction in the blended juice samples.

To our knowledge, this study represents the first published work on the survival and growth characteristics of $E$. coli $\mathrm{O} 157: \mathrm{H} 7$ in pomegranate juice and blend juice. Based on the results, pomegranate juice could be added to other natural juices such as carrot and apple as a source of antimicrobial agent and a nutrient food additive. The use of pomegranate as natural ingredient is only one of the practical methods in the farm to fork continuum to ensure safety of our food supply. Additional work is needed to determine the effect of pomegranate juice in combination with other natural ingredients such as organic acids, or non thermal approach to control the risk of foodborne pathogens in food products. Because pomegranate juice has a high nutritional and health value, and desirable flavor and beautiful color, it could improve the sensory characteristics and consumer acceptance of natural juices with lower taste desirability such as carrot juice. Together with its antimicrobial properties; pomegranate juice could be used as a natural antimicrobial ingredient to control the growth of foodborne pathogens. Further experiments need to be conducted for the sensory evaluation of different blends.

\section{Acknowledgements}

The research work was funded through the Cooperative State Research, Education and Extension Service of the United States Department of Agriculture, Project No. NC.X173-5-02-170-1, in the Agricultural Research Program, North Carolina Agricultural and Technical State University. We like to express our gratitude to Dr. C.S. Turner, Associate Dean for Research for her support and Dr. K.J. Gruber and Sangeetha Viswanathan for their review and comments on this manuscript.

\section{REFERENCES}

[1] R. L. Buchanan and M. P. Doyle, "Foodborne Disease Significance of Escherichia coli O157:H7 and Other EnteroHemorrhagic E-coli," Food Technology, Vol. 51, No. 10, 1997, pp. 69-76.

[2] P. S. Mead, L. Slutsker, V. Dietz, L. F. McCaig, J. S. Bresee, C. Shapiro, P. M. Griffin and R. V. Tauxe, "Food-Related Illness and Death in the United States," Emerging Infectious Diseases, Vol. 5, No. 5, 1999, pp. 607-625. doi:10.3201/eid0505.990502

[3] P. Feng, "Escherichia-Coli Serotype O157-H7-Novel Vehicles of Infection and Emergence of Phenotypic Variants," Emerging Infectious Diseases, Vol. 1, No. 2, 1995, pp. 47-52. doi:10.3201/eid0102.950202

[4] P. Pathanibul, T. M. Taylor, P. M. Davidson and F. Harte, "Inactivation of Escherichia coli and Listeria Innocua in Apple and Carrot Juices Using High Pressure Homogenization and Nisin," International Journal of Food Microbiology, Vol. 129, No. 3, 2009, pp. 316-320. doi:10.1016/j.ijfoodmicro.2008.12.020

[5] L. L. Zaika, "Spices and Herbs-Their Antimicrobial Activity and Its Determination," Journal of Food Safety, Vol. 9, No. 2, 1988, pp. 97-118. doi:10.1111/j.1745-4565.1988.tb00511.x

[6] M. M. Tajkarimi, S. A. Ibrahim and D. O. Cliver, "Antimicrobial Herb and Spice Compounds in Food," Food Control, Vol. 21, No. 9, 2010, pp. 1199-1218. doi:10.1016/j.foodcont.2010.02.003

[7] M. M. Theron and J. F. R. Lues, "Organic Acids and Meat Preservation: A Review," Food Reviews International, Vol. 23, No. 2, 2007, pp. 141-158. doi:10.1080/87559120701224964

[8] E. Block, S. Naganathan, D. Putman and S. H. Zhao, "Allium Chemistry-Hplc Analysis of Thiosulfinates from Onion, Garlic, Wild Garlic (Ramsoms), Leek, Scallion, Shallot, Elephant (Great-Headed) Garlic, Chive and Chinese Chive--Uniquely High Allyl to Methyl Ratios in Some Garlic Samples," Journal of Agricultural and Food Chemistry, Vol. 40, No. 12, 1992, pp. 2418-2430. doi:10.1021/jf00024a017

[9] G. C. Yang, S. A. Ibrahim and C. E. Niedziela, "Antimicrobial Effect of Guava Products against Foodborne Pathogens," Hortscience, Vol. 39, No. 4, 2004, pp. 778-778.

[10] F. H. M. Mokbel, "Antibacterial and Antioxidant Activities of Banana (Musa, AAA cv. Carendish) Fruits Pee," Food Chemistry, Vol. 94, 2005, pp. 529-534. doi:10.1016/j.foodchem.2004.11.042

[11] A. Furiga, A. Lonvaud-Funel and C. Badet, "In vitro Study of Antioxidant Capacity and Antibacterial Activity on Oral Anaerobes of a Grape Seed Extract," Food Chemistry, Vol. 113, No. 4, 2009, pp. 1037-1040. doi:10.1016/j.foodchem.2008.08.059

[12] S. A. Ibrahim, H. Yang and C. W. Seo," Antimicrobial Activity of Lactic Acid and Copper on Growth of Salmo- 
nella and Escherichia Coli O157:H7 in Laboratory Medium and Carrot Juice, "Food Chemistry, Vol. 109, No. 1, 2008, pp. 137-143. doi:10.1016/j.foodchem.2007.12.035

[13] V. C. H. Wu, X. J. Qiu and Y. H. P. Hsieh, "Evaluation of Escherichia coli O157:H7 in Apple Juice with Cornus Fruit (Cornus Officinalis Sieb. et Zucc.) Extract by Conventional Media and Thin Agar Layer Method," Food Microbiology, Vol. 25, No. 1, 2008, pp. 190-195. doi:10.1016/j.fm.2007.09.005

[14] L. U. Opara, M. R. Al-Ani and Y. S. Al-Shuaibi, "Physicochemical Properties, Vitamin C Content, and Antimicrobial Properties of Pomegranate Fruit (Punica granatum L.)," Food and Bioprocess Technology, Vol. 2, No. 3, 2009, pp. 315-321. doi:10.1007/s11947-008-0095-5

[15] M. Aviram, L. Dornfeld, M. Rosenblat, N. Volkova, M. Kaplan, R. Colemann, T. Hayek, D. Presser and B. Fuhrman, "Pomegranate Juice Consumption Reduces Oxidative Stress, Atherogenic Modifications to LDL, and Platelet Aggregation: Studies in Humans and in Atherosclerotic Apolipoprotein E-Deficient Mice," American Journal of Clinical Nutrition, Vol. 71, No. 5, 2000, pp. 1062-1076.

[16] S. G. Kasimsetty, D. Bialonska, M. K. Reddy, C. Thornton, K. L. Willett and D. Ferreira, "Effects of Pomegranate Chemical Constituents/Intestinal Microbial Metabolites on CYP1B1 in 22Rv1 Prostate Cancer Cells," Journal of Agricultural and Food Chemistry, Vol. 57, No. 22, 2009, pp. 10636-10644. doi:10.1021/jf902716r

[17] D. Prashanth, M. K. Asha and A. Amit, "Antibacterial Activity of Punica Granatum," Fitoterapia, Vol. 72, No. 2, 2001, pp. 171-173. doi:10.1016/S0367-326X(00)00270-7

[18] P. S. Negi and G. K. Jayaprakasha, "Antioxidant and Antibacterial Activities of Punica Granatum Peel Extracts," Journal of Food Science, Vol. 68, No. 4, 2003, pp. 1473-1477. doi:10.1111/j.1365-2621.2003.tb09669.x

[19] S. Voravuthikunchai, A. Lortheeranuwat, W. Jeeju, T. Sririrak, S. Phongpaichit and T. Supawita, "Effective MediCinal Plants against Enterohaemorrhagic Escherichia coli O157:H7," Journal of Ethnopharmacology, Vol. 94, No. 1, 2004, pp. 49-54. doi:10.1016/j.jep.2004.03.036

[20] L. C. Braga, J. W. Shupp, C. Cummings, M. Jett, J. A. Takahashi, L. S. Carmo, E. Chartone-Souza and A. M. A. Nascimento, "Pomegranate Extract Inhibits Staphylococcus Aureus Growth and Subsequent Enterotoxin Production," Journal of Ethnopharmacology, Vol. 96, No. 1-2, 2005, pp. 335-339. doi:10.1016/j.jep.2004.08.034

[21] P. S. N. G. K. Jayaprakasha and B. S. Jena, "Pomegranates: Ancient Roots to Modern Medicine," CRC Press, Boca Raton, 2006.
[22] S. Naz, R. Siddiqi, S. Ahmad, S. Rasool and S. A. Sayeed, "Antibacterial Activity Directed Isolation of Compounds from Punica Granatum," Journal of Food Science, Vol. 72, No. 9, 2007, pp. M341-M345. doi:10.1111/j.1750-3841.2007.00533.x

[23] M. K. Reddy, S. K. Gupta, M. R. Jacob, S. I. Khan and D. Ferreira, "Antioxidant, Antimalarial and Antimicrobial Activities of Tannin-Rich Fractions, Ellagitannins and Phenolic Acids from Punica Granatum L.," Planta Medica, Vol. 73, No. 5, 2007, pp. 461-467. doi:10.1055/s-2007-967167

[24] N. S. Al-Zoreky, "Antimicrobial Activity of Pomegranate (Punica Granatum L.) Fruit Peels," International Journal of Food Microbiology, Vol. 134, No. 3, 2009, pp. 244248. doi:10.1016/j.ijfoodmicro.2009.07.002

[25] A. K. Sarkar and R. Dhandapani, "Study of Natural Colorants as Antibacterial Agents on Natural Fibers," Journal of Natural Fibers, Vol. 6, No. 1, 2009, pp. 46-55. doi:10.1080/15440470802704370

[26] D. L. Lucas and L. M. Were, “Anti-Listeria Monocytogenes Activity of Heat-Treated Lyophilized Pomegranate Juice in Media and in Ground Top Round Beef," Journal of Food Protection, Vol. 72, No. 12, 2009, pp. 2508-2516.

[27] M. Tajkarimi and S. A. Ibrahim, "Antimicrobial Activity of Ascorbic Acid Alone or in Combination with Lactic Acid on Escherichia coli O157:H7 in Laboratory Medium and Carrot Juice," Food Control, Vol. 22, No. 6, 2011, pp. 801-804. doi:10.1016/j.foodcont.2010.11.030

[28] H. Alighourchi, M. Barzegar and S. Abbasi, "Effect of Gamma Irradiation on the Stability of Anthocyanins and Shelf-Life of Various Pomegranate Juices," Food Chemistry, Vol. 110, No. 4, 2008, pp. 1036-1040. doi:10.1016/j.foodchem.2008.03.013

[29] D. Bialonska, P. Ramnani, S. G. Kasimsetty, K. R. Muntha, G. R. Gibson and D. Ferreira, "The Influence of Pomegranate by-Product and Punicalagins on Selected Groups of Human Intestinal Microbiota," International Journal of Food Microbiology, Vol. 140, No. 2-3, 2010, pp. 175-182. doi:10.1016/j.ijfoodmicro.2010.03.038

[30] H. Corke, B. Shan, Y. Z. Cai and J. D. Brooks, "Potential Application of Spice and Herb Extracts as Natural Preservatives in Cheese," Journal of Medicinal Food, Vol. 14, No. 3, 2011, pp. 284-290. doi:10.1089/jmf.2010.0009

[31] P. Uchgaonkar and N. Dahiya, "Phytochemical Analysis and Antibacterial Activity of Punica granatum L. Rind Extracts on Common Enteric Pathogens," Journal of Pure and Applied Microbiology, Vol. 5, No. 1, 2011, pp. 417-420. 